\title{
EFFECT OF 12.5\% VIRGIN COCONUT OIL ON PORPHYROMONAS GINGIVALIS AND TREPONEMA DENTICOLA BACTERIAL COLONIZATION
}

\author{
RATNA SARI DEWI ${ }^{1 *}$, FARISZA GITA ${ }^{1}$, BOY BAHTIAR ${ }^{2}$, HOCKY BENNY KASIM ${ }^{1,2}$ \\ ${ }^{1}$ Department of Prosthodontics, Faculty of Dentistry, Universitas Indonesia, Jakarta, Indonesia. ${ }^{2}$ Department of Oral Biology, Faculty of \\ Dentistry, Universitas Indonesia, Jakarta, Indonesia. Email: ratnasaridewi.drg@gmail.com
}

Received: 16 September 2017, Received and Accepted: 17 September 2017

\section{ABSTRACT}

Objective: Gram-negative bacteria in the oral cavity such as Porphyromonas gingivalis and Treponema denticola can adhere on the surface area of the tooth and also in the subgingival area as a biofilm. In this research, pure coconut oil $12.5 \%$ mouthwash is used with fermentation method, while based on earlier research using a concentration above $12.5 \%$ showed that an antibacterial effect from pure coconut oil will decrease the number of microorganism.

Aim: The aim of this study was to analyze the clinical effect microbiological of pure coconut oil $12.5 \%$ on the decrease in a number of bacteria P. gingivalis and T. denticola on the margin of porcelain fused to metal crown.

Methods: 23 subjects, were patients with porcelain fused to metal crown in posterior of Faculty of Dentisty Universitas Indonesia 'dental hospital. They fill the informed consent, clinical periodontal examination. Patients were gargled twice daily with a pure coconut oil $12.5 \%$ of $30 \mathrm{cc}$ for 1 min performed for 4 days. Sampling of saliva were collected with paper point for calculating the number of bacteria P. gingivalis and T. denticola using real-time polymerase chain reaction.

Conclusion: Using Pure coconut oil $12.5 \%$ showed decrease amount of bacteria P. gingivalis and T. denticola in the margin porcelain fused to metal crown.

Keywords: Virgin coconut oil (VCO)12.5\%, Porphyromonas gingivalis, Treponema denticola, Bacterial colonization.

(C) 2017 The Authors. Published by Innovare Academic Sciences Pvt Ltd. This is an open access article under the CC BY license (http://creativecommons. org/licenses/by/4. 0/) DOI: http://dx.doi.org/10.22159/ijap.2017.v9s2.09

\section{INTRODUCTION}

Dental treatment using a fixed prosthesis aims to maintain the good function of the remaining teeth along with that of the mastication system. Periodontal support of the abutment teeth, particularly in the case of a fixed prosthesis, could affect the treatment outcome. The use of a fixed prosthesis is considered to be successful if the restoration remains in place for a long period of time without causing any periodontal tissue abnormalities. Many studies have shown the close relationship between the use of a fixed prosthesis and the risk of periodontal tissue inflammation [1,2]. For instance, Socransky declared that bacterial elimination is required to prevent the risk of periodontal tissue infection [3]. Initially, the periodontitis begins with the normal bacterial flora within the oral cavity. After that, it changes into a pathogen, which is particularly problematic around the teeth, since local factors could exacerbate the occurrence of abnormalities [1].

Gram-negative microorganisms, for example, Porphyromonas gingivalis, Tannerella forsythia, and Treponema denticola dominate the subgingival region and organize as biofilms [4]. Further, the presence of these Gramnegative microorganisms in the subgingival area of the metal-porcelain full veneer crown margins can cause inflammation in the periodontal tissues.

During the manufacture of a fixed prosthesis, a number of factors must be considered, including biological considerations affecting tissue health, mechanical considerations affecting integrity and resilience, and esthetic considerations affecting the patient's appearance [6]. Both improper margin positioning and edges that meet the contour of the gingiva can cause difficulties in achieving plaque control, which could result in a long-term barrier to the maintenance of tissue health as well as problems with the fixed prosthesis itself.
The contours of the crown, the placement of the margins, and the design of a pontic all greatly affect the health of the periodontal tissue [7]. The crown contours should be properly made to avoid the accumulation of plaque. Subgingival margin placement encourages the accumulation of plaque and gingival inflammation, although the incidence of several new caries has recently been associated with the placement of the supragingival margins [8].

The imbalance influenced by ecosystem factors stemming from the oral flora of the oral cavity can cause a fixed prosthesis to become the location for plaque growth and the development of microorganisms. Most plaques consist of approximately 500 species of microorganisms. Further, dental plaques can be classified as either supragingival or subgingival plaques based on their position in relation to the gingival surface.

Supragingival plaque is found above the gingival margin, while subgingival plaque is found below the gingival margin between the tooth and the gingival pocket. The subgingival microbiota composition differs from that of the supragingival microbiota. Supragingival plaque is dominated by stem bacteria and Gram-positive cocci, while the bacteria that dominate the subgingival region vary, depending on the depth of the pocket. Gram-negative anaerobic bacteria are found in the subgingival margin area, for example, P. gingivalis and T. denticola microorganisms.

The use of a mouthwash is widely recommended due to it helping to maintain the normal flora balance of the oral cavity.

\section{Virgin coconut oil (VCO)}

VCO contains lauric acid, caprylic acid, and capric acid, which have antiviral, antibacterial, antifungal, and antiprotozoal effects. The numerous advantages of lauric acid, that is, the largest component of 
VCO, could eliminate various microorganisms whose cell membranes contain fat, including Streptococcus sp., Gram-positive bacteria, and Gram-negative bacteria. The VCO used in this research study was developed using the fermentation method to achieve a concentration of $12.5 \%$. This concentration was chosen based on the research by Hasriati et al., who found that the antibacterial effect of VCO starts to decrease after a concentration of $12.5 \%$. Ogbolu et al. proved that VCO concentrations of $0.79 \%, 50 \%$, and $100 \%$ have antifungal effects on various Candida fungi. According to Saputry, gargling using VCO with a concentration of $20 \%$ is not effective in reducing the amount of colonies of dental plaque bacteria in subjects with normal oral health.

\section{P. gingivalis}

The bacteria associated with chronic periodontitis are P. gingivalis [24]. Such bacteria are rod-shaped, non-motile, anaerobic, Gram-negative, and asaccharolytic, and they produce black-pigmented colonies. These bacteria are incorporated within the red complex associated with bleeding following probing and dominant over the development of advanced plaque.

One of the pathogenic factors of $P$. gingivalis is the gingipains, which are proteinase enzymes specific to arginine and lysine. Gingipains influence the progression of periodontal disease by increasing vascular permeability and stimulating cells to produce inflammatory mediators and accumulate neutrophils. The accumulation of neutrophils will increase the activation of the gingival crevice fluid granular proteinase and damage the bonding tissue, thereby creating a conducive environment for the development of subgingival bacteria.

\section{T. denticola}

T. denticola is anaerobic spirochete and also a Gram-negative and spiral-shaped bacteria. Their presence is increased in cases of chronic periodontitis. The hallmark of spirochete infection is its ability to invade tissue [25]. T. denticola induces and degrades the cytokines. Further, T. denticola causes the inhibition of migration from the fibroblasts and neutrophils by means of interfering with the neutrophils' ability to eliminate pathogenic bacteria and affecting the fibroblasts' activity in wound healing. The virulence factors of $T$. denticola bacteria include some proteins associated with flagella synthesis, chemotaxis proteins, denticillin, and proteases shaped like chymotrypsin.

\section{METHODS}

This study was conducted using a clinical experimental method. The subjects were using metal-porcelain full veneer crown(s) who were treated at the Prosthodontics Clinic of University Dental Hospital, Faculty of Dentistry, University of Indonesia (RSKGM FKG UI), between January and March 2017

\section{RESULTS}

This study was conducted on 23 subjects with metal-porcelain full veneer crown(s) who were included in the study based on inclusion and exclusion criteria. The research was conducted from January 2017 to March 2017, and the ethical approval for the study was granted by the Ethics Commission of the Faculty of Dentistry, University of Indonesia. Sampling was conducted at the Prosthodontics Clinic of University Dental Hospital Faculty of Dentistry, University of Indonesia.

The primary data collection involved questionnaires, the signing of an informed consent form, examination of the subjects' periodontal status, and sampling of their subgingival plaque.

The subgingival plaque sampling was performed on all subjects with $4 \mathrm{~mm}$ pocket depth criteria to obtain a total of 23 subgingival plaque samples. The subjects were instructed to rinse with $12.5 \%$ VCO twice daily for 4 days after brushing their teeth in the morning and at the night before bed. They were told to gargle for $30 \mathrm{~s}$ using the dosage provided and then remove the VCO without rinsing with water. A laboratory examination involving a real-time polymerase chain reaction (RT-PCR) was performed in the Oral Biology Laboratory Faculty of Dentistry University of Indonesia.

Fig. 1 presents the results of the univariate analysis comparing the total overall bacterial count with the number of $P$. gingivalis and T. denticola bacteria. The figure shows that the computed tomography (CT) mean of the T. denticola is higher than the CT mean of the total bacteria and also higher than the CT mean of the P. gingivalis (30.22), although the CT mean of the total bacteria is lower than the CT mean of the P. gingivalis and the CT mean of the T. denticola (20.43).

Fig. 2 illustrates the mean overall value of the data obtained from the 23 subjects. The figure shows that the highest CT mean was obtained for subject 6, with the CT mean of the P. gingivalis being 35.53 .

Overall, it can be seen that the total CT mean is always lower than the CT mean of the P. gingivalis and the CT mean of the T. denticola in all subjects.

\section{DISCUSSION}

This study was a clinical experimental study in which each subject served as the control for him/herself. The purpose of this study was to analyze the influence of the use of $12.5 \%$ VCO in decreasing the number of $P$. gingivalis and $T$. denticola bacteria on the metal-porcelain full veneer crown margins.

Table 1: CT mean of bacteria

\begin{tabular}{lllll}
\hline Treatment & Mean & t & df & Significant \\
\hline Before & 1.227 & 3.679 & 5 & $0.014 \mathrm{~s}$ \\
$P g$ & - & & & \\
After & 0.036 & & & \\
Before & 0.0816 & 2.857 & 5 & $0.036 \mathrm{~s}$ \\
Td & - & & & \\
After & 0.004 & & & \\
\hline
\end{tabular}

Pg: Porphyromonas gingivalis bacteria, Td: Treponema denticola bacteria., t-test: $\mathrm{p}<0.05$, CT: Computed tomography, s: Significant

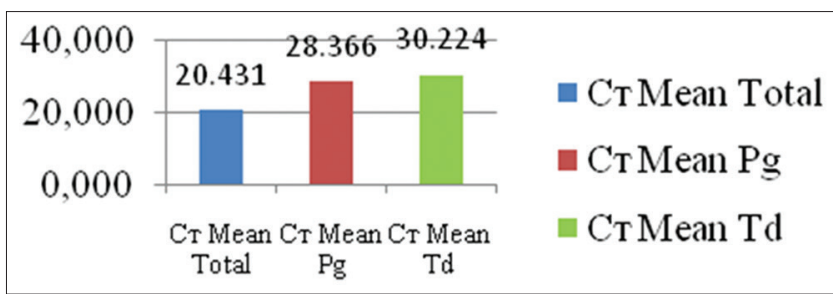

Fig. 1: Results of the total bacterial test on Porphyromonas gingivalis and Treponema denticola

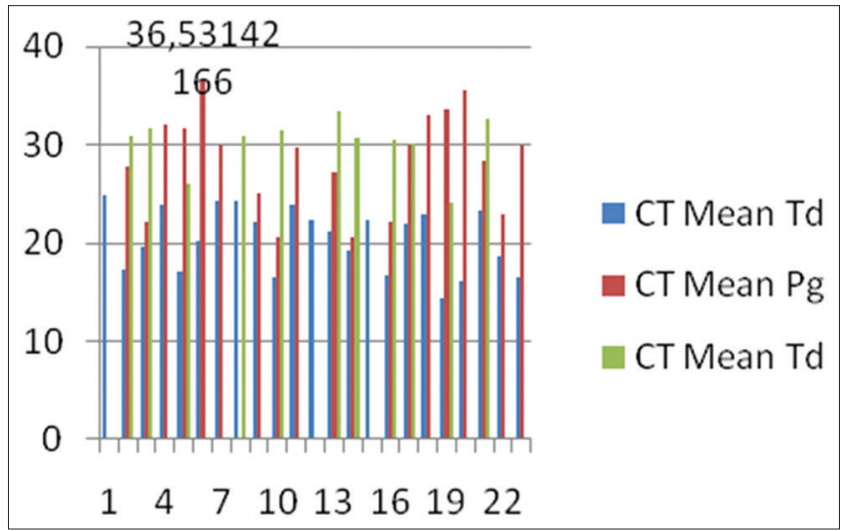

Fig. 2: Central tendency mean of all data 
Samples were taken from the subjects at the beginning of the study, and the subjects were given four $30 \mathrm{ml}$ bottles of $12.5 \%$ VCO to be used for 4 days. They were instructed to rinse twice daily for $30 \mathrm{~s}$ according to the dosage and removed the VSO without rinsing with water. After 4 days, the subjects returned so that a control sample could be taken.

The subgingival sampling could be performed with a scaler, a curette, or paper points. Loomer reported that samples taken with paper points differ from those obtained using a curette. Curettage takes plaque from all areas of the pocket, including the most apical area, while paper points only take the outside of the coronal plaque. The plaque sampling in this study was conducted using paper points to reduce the likelihood of bleeding during sampling. The disadvantage of using paper points was the inability to reach the bottom of the pocket.

Pocket depth measurements were performed for all study subjects. The pocket depth was measured on six tooth surfaces (mesiobuccal, midbuccal, distobuccal, mesiolingual, midlingual, and distolingual) using a periodontal probe [21]. A measurement depth of $4 \mathrm{~mm}$ was selected for the subgingival plaque sampling. The selection of the pocket depth was based on the study by Passariello et al., who found that $P$. gingivalis and T. denticola are most commonly found in subgingival plaques at pocket depths $>4 \mathrm{~mm}$. T. denticola is found on the surface of the plaque at a depth of 4-6 mm, while $P$. gingivalis is found in the deeper layers [35]. In Fig. 1, the total bacteria test results concerning the $P$. gingivalis and $T$. denticola indicate large numbers of bacteria in the subgingival region. In Fig. 2, subject six has the highest mean value of $P$. gingivalis bacteria (35.53).

Quantitative calculations concerning the $P$. gingivalis and T. denticola bacteria were performed using a RT-PCR. This method was chosen because it is easy, fast, accurate, and generates reliable measurement results [28]. The descriptive statistical results for the $P$. gingivalis bacteria before treatment gave an average of 1.23 , with a standard deviation of 0.82 , a minimum value of 0.000 , and a maximum value of 1.85. The results after treatment for the $P$. gingivalis bacteria gave an average of 0.036 , with a standard deviation of 0.040 , a minimum value of 0.000 , and a maximum value of 0.080 . Before treatment, the T. denticola bacteria had an average value of 0.816 , with a standard deviation of 0.694 , a minimum value of 0.000 , and a maximum value of 1.624. Then, after treatment, the T. denticola bacteria had an average value of 0.004 , with a standard deviation of 0.009 , a minimum value of 0.000 , and a maximum value of 0.022 .

Based on the results, it can be concluded that the significance value of the P. gingivalis bacteria before and after treatment is $0.014(\mathrm{p}<0.05)$. Similarly, the results of the independent t-test on the T. denticola bacteria before and after treatment show a significance value of $0.036(\mathrm{p}<0.05)$.

VCO contains lauric acid, caplyric acid, and capric acid, which have antiviral, antibacterial, antifungal, and antiprotozoal effects. Lauric acid could serve to eliminate various microorganisms whose cells membranes contain fat, including Streptococcus sp., Gram-positive bacteria, and Gram-negative bacteria.

The use of $12.5 \%$ VCO significantly decreased the amount of P. gingivalis and $T$. denticola bacteria on the metal-porcelain full veneer porcelain margin. The VCO concentration of $12.5 \%$ was chosen based on the study by Hasriati et al., who noted that the antibacterial effect of $12.5 \%$ VCO showed a decrease in bacterial colonization. Dewi et al. found that VCO $12.5 \%$ VCO have a significant effect when compared with aquadest, while decreasing the gingival index of bridge restoration users. According to Saputry, VCO mouthwash with a concentration of $20 \%$ does not effectively decrease the amount of plaque bacterial colonization in subjects with normal oral hygiene.

\section{CONCLUSION}

Based on the results of this study, it can be concluded that the usage of VCO mouthwash with a concentration of $12.5 \%$ effectively decreases the amount of $P$. gingivalis and T. Denticola bacterial colonization on the metal-porcelain full veneer crown margins.

\section{ACKNOWLEDGMENT}

The publication of this manuscript is supported by Universitas Indonesia

\section{REFERENCES}

1. Syafril Y. The diagnosis of periodontal disease in periodontal clinic, dental hospital, university of Indonesia. In: Bartold M, editor. Current trends in Periodontal Diagnosis, Disease Recognition and Management. Brisbane: Asian Pacific Society of Periodontology; 2003. p. 34-8.

2. Goodacre CJ, Bernal G, Rungcharassaeng K, Kan JY. Clinical complications in fixed prosthodontics. J Prosthet Dent 2003;90:31-41.

3. Socransky SS. Relationship of bacteria to the etiology of periodontal disease. J Dent Res 1970;49:203-22.

4. Socransky SS, Haffajee AD, Cugini MA, Smith C, Kent RL Jr. Microbial complexes in subgingival plaque. J Clin Periodontol 1998;25:134-44.

5. Rosenstiel SF, Land MF, Fujimoto J, editors. The metal ceramic crown preparations. Contemporary Fixed Prosthodontics. $4^{\text {th }}$ ed., Vol. 7. St. Louis, Missouri: Mosby, Inc.; 2006. p. 272-85.

6. Rosenstiel SF, Land MF, Fujimoto J, editors. Principles of tooth preparation. Contemporary Fixed Prosthodontics. $4^{\text {th }}$ ed., Vol. 7. St. Louis, Missouri: Mosby, Inc.; 2006. p. 209-57.

7. Becker CM, Kaldahl WB. Current theories of crown contour, margin placement, and pontic design 1981. J Prosthet Dent 2005;93:107-15.

8. Durr-E-Sadaf, Ahmad Z. Porcelain fused to metal (PFM) crowns and caries in adjacent teeth. J Coll Physicians Surg Pak 2011;21:134-7.

9. Newman M, Takei H, Klokkevold P, Carranza F, editors. Periodontal microbiology. Carranza's Clinical Periodontology. $11^{\text {th }}$ ed. St. Louis: Elsevier Saunders; 2011. p. 232-70

10. Shillingburg HT, Sather DA, Wilson EL Jr, Cain JR, Mitchell DL, Blanco LJ, et al. Fundamentals of Fixed Prosthodontics. $4^{\text {th }}$ ed. Hanover Park, IL: Quintessence; 2012. p. 353-78.

11. Lesmana RA. Faktor-Faktor Periodontal Yang Harus Dipertimbangkan Pada Perawatan Dengan Gigi Tiruan Cekat. Vol. 6. Jakarta: Jurnal Kedokteran Gigi Universitas Indonesia; 1999. p. 34-43.

12. Lang NP, Kiel RA, Anderhalden K. Clinical and microbiological effects of sub gingival restorations with overhanging or clinically perfect margins. J Clin Periodontol 1983;10:563-78.

13. Chatterjee U. Margin designs for esthetic restoration: An overview. J Adv Oral Res 2012;3:7-11.

14. Limkangwalmongkol P, Chiche GJ, Blatz MB. Precision of fit of two margin designs for metal-ceramic crowns. J Prosthodont 2007;16:233-7.

15. Ovais N, Ahmed B, Azadet AA, Aal A. Mind the crown margins. Pak Oral Dent J 2015;35:307-11

16. Devaki V. Marginal fit of metal ceramic restorations with various finish lines: An in vitro study. Dissertation. Madras: University of Tamil Nadu DR. M.G.R. Medical; 2005.

17. Boeckler AF, Stadler A, Setz JM. The significance of marginal gap and overextension measurement in the evaluation of the fit of complete crowns. J Contemp Dent Pract 2005;6:26-37.

18. Rahshenas N, Motamedi MH, Nazari MS, Salari MH. Effect of shoulder and deep chamfer finish line on marginal fitness of electroformed P.F.M. Restorations. J Interdiscipl Med Dent Sci 2014;2:145-7.

19. Ruiz JL. Supra gingival dentistry using metal-free restorations. Dent Today 2009;25:80-6.

20. Christensen GJ. The state of fixed prosthodontics impressions: Room for improvement. J Am Dent Assoc 2005;136:343-6.

21. Varga J, Denton CP, Wigley FM, Allanore Y, Kuwana M. Scleroderma: From Pathogenesis to Comprehensive Management. Louis: Elsevier Saunders; 2011. p. 160-4.

22. Reddy S, editor. Chronic periodontitis. Essentials of Clinical Periodontology and Periodontics. New Delhi: Jaypee Brothers Med Publication; 2008. p. 205-9.

23. Bathla S, editor. Dental plaque. Periodontics Revisited. New Delhi: Jaypee Brothers Medical; 2011. p. 65-71.

24. Bathla S, editor. Periodontal microbiology. Periodontics Revisited. New Delhi: Jaypee Brothers Medical; 2011. p. 59-64.

25. Orth RK, O'Brien-Simpson NM, Dashper SG, Reynolds EC. Synergistic virulence of Porphyromonas gingivalis and Treponema denticola in a murine periodontitis model. Mol Oral Microbiol 2011;26:229-40.

26. Engelberger T, Hefti A, Kallenberger A, Rateitschak KH. Correlations among papilla bleeding index, other clinical indices and histologically 
determined inflammation of gingival papilla. J Clin Periodontol 1983; 10:579-89.

27. Carranza FA, Takei HH. Clinical diagnosis. In: Newman MG, Takei HH, Klokkevold PR, Carranza FA, editors. Carranza's Clinical Periodontology. 10 $10^{\text {th }}$ ed. St. Louis, Missouri: Saunders Co.; 2006. p. $540-60$.

28. Life Technologies. Introduction. In: Real Time PCR Handbook. $6^{\text {th }}$ ed. New York: Life Technologies; 2012. p. 3-20.

29. Alamsyah AN. Mengenal lebih dekat virgin coconut oil. Minyak Penakluk Aneka Penyakit. Jakarta: Argomedia Pustaka; 2005. p. 86.

30. Ogbolu DO, Oni AA, Daini OA, Oloko AP. In vitro antimicrobial properties of coconut oil on candida species in Ibadan, Nigeria. J Med Food 2007; 10:384-7

31. Hasriati E. Pengaruh Virgin Coconut Oil (VCO) Hasil Fermentasi Terhadap Pertumbuhan dan Profit Protein Streptococcus mutans Serotip C Secara in vitro, Skripsi. Jakarta: Departemen Biologi Oral Fakultas Kedokteran Gigi Universitas Indonesia; 2007.

32. Saputry DP. Pengaruh Berkumur Menggunakan Virgin Coconut Oil Konsentrasi 20\% Terhadap Jumlah Koloni Bakteri Plak Gigi, Skripsi. Jogjakarta: Fakultas Kedokteran Gigi Universitas Gadjah Mada; 2014

33. Yonadi PS. Study of Making virgin coconut oil (VCO) enzyme using different concentration og enzyme of pinnaple on the two type og coconut J Agroqua 2013;1:24-8.

34. Passariello C, Puttini M, Virga A, Gigola P. Microbiological and host factors are involved in promoting the periodontal failure of metal ceramic crowns. Clin Oral Investig 2012;16:987-95.

35. Kigure T, Saito A, Seida K, Yamada S, Ishihara K, Okuda K. Distribution of Porphyromonas gingivalis and Treponema denticola in human sub gingival plaque at different periodontal pocket depths examined by immunohistochemical methods. J Periodontal Res 1995;30:332-41.

36. Loomer PM. Microbiological diagnostic testing in the treatment of periodontal diseases. Periodontol 2000;34:49-56

37. Dewi RS, Nuning F. Pengaruh Obat Kumur VCO (Virgin Coconut Oil)12.5\% Terhadap Penurunan Indeks Gingiva. Jakarta: Jurnal Kedokteran Gigi Universitas Indonesia; 2012.

38. Bangash RY, Khan AU, Tariq KM, Rasheed D. Evaluation of tooth brushing technique and oral hygiene knowledge at Afid, Rawalpindi. Pak Oral Dent J 2012;1:124-7.

39. Khaki MN, Mohajerfar M, Ejlalai M, Tvakolizadeh S. Evaluation of pound concept in determination of mediolateral mandibular posterior teeth position. J Dent Mater Tech 2017;6:7-10. 